\title{
Group 1 metabotropic glutamate receptor function and its regulation of learning and memory in the aging brain
}

\section{Caroline Ménard* and Rémi Quirion}

Department of Psychiatry, Douglas Mental Health University Institute, McGill University, Montreal, QC, Canada

Edited by:

Andrew Lawrence, Florey

Neuroscience Institutes, Australia

\section{Reviewed by:}

Kuei Y. Tseng, Rosalind Franklin

University of Medicine and Science, USA

Daniela Brunner, PsychoGenics, USA Sean McBride, University of

Pennsylvania, USA

*Correspondence:

Caroline Ménard, Douglas Mental Health University Institute, Perry Pavilion, Room E-2118, 6875 LaSalle Boulevard, Montreal, QC, Canada H4H 1 R3.

e-mail: caroline.menard@douglas. mcgill.ca
Normal aging is generally characterized by a slow decline of cognitive abilities albeit with marked individual differences. Several animal models have been studied to explore the molecular and cellular mechanisms underlying this phenomenon. The excitatory neurotransmitter glutamate and its receptors have been closely linked to spatial learning and hippocampus-dependent memory processes. For decades, ionotropic glutamate receptors have been known to play a critical role in synaptic plasticity, a form of adaptation regulating memory formation. Over the past 10 years, several groups have shown the importance of group 1 metabotropic glutamate receptor (mGluR) in successful cognitive aging. These Gprotein-coupled receptors are enriched in the hippocampal formation and interact physically with other proteins in the membrane including glutamate ionotropic receptors. Synaptic plasticity is crucial to maintain cognitive abilities and long-term depression (LTD) induced by group 1 mGluR activation, which has been linked to memory in the aging brain. The translation and synthesis of proteins by mGluR-LTD modulate ionotropic receptor trafficking and expression of immediate early genes related to cognition. Fragile $X$ syndrome, a genetic form of autism characterized by memory deficits, has been associated to mGluR receptor malfunction and aberrant activation of its downstream signaling pathways. Dysfunction of $m$ mluR could also be involved in neurodegenerative disorders like Alzheimer's disease (AD). Indeed, beta-amyloid, the main component of insoluble senile plaques and one of the hallmarks of AD, occludes mGluR-dependent LTD leading to diminished functional synapses. This review highlights recent findings regarding mGluR signaling, related synaptic plasticity, and their potential involvement in normal aging and neurological disorders.

Keywords: metabotropic glutamate receptors, aging, learning, memory, synaptic plasticity

\section{AGING AND COGNITION}

Over the next decades, a majority of developing countries will face one of the biggest challenges in history: accelerated aging of its populations. In human, aging is characterized by physical, psychological, and social changes. Interestingly, major individual differences are known to exist and low probability of disease and disability, high cognitive and physical capacity, and active engagement in life in general are associated to successful aging. Several animal models have been developed to investigate the processes behind this phenomenon (Gallagher et al., 2011). Indeed, it is important to understand not only how to increase lifespan but maintain quality of life.

One of the most dreaded and studied feature of aging is related to cognitive dysfunctions. Therefore, behavioral studies of rodent animal models are useful to explore mechanisms underlying memory deficits associated to aging. The Morris Water Maze (MWM) test was introduced in 1984, to study hippocampusdependent memory in rats (Morris, 1984). The hippocampus is crucial for working memory and particularly spatial learning. Briefly, a platform is hidden under opaque water and the animal has to learn the platform position using visual clues over a daily training period. Aging generally affects the time the rat will take to reach the platform, when performances are compared to young animals. For the Long-Evans rat strain however, a subgroup of old animals maintains high cognitive abilities despite aging while another sub-group shows mild cognitive impairments, thus making this model suitable to explore successful aging processes (Gallagher et al., 1993; Menard and Quirion, 2012). Cognition is not limited to spatial memory. Reactivity to novelty and gustatory/olfactory memory, another form of cognition involving multiple neuronal networks and brain areas, is also deficient in old memory-impaired Long-Evans rats, while aged memoryunimpaired animals cope well with environmental changes (Rowe et al., 1998). Other forms of memories have not yet been tested in this rat strain. While cognition include more than formation of memories, we chose to focus on learning and consolidation of long-term memories for this review. For more information on other cognitive processes in aged rat models such as attention, rule reversal, discrimination, working memory, and the different circuits involved, please refer to Gallagher et al. (2011). Multiple rat models should be studied to unravel the impact of aging on cognition. Indeed, Sprague-Dawley rats show faster acquisition than Long-Evans rats for a five-choice serial reaction time examining multiple aspects of cognition and executive functions (Auclair et al., 2009). Aging could differentially affect these processes. 
Early on, alterations in cholinergic neuronal activity were linked to memory impairments in the Long-Evans rat model (Aubert et al., 1995). More recently, gene expression has been compared as a function of age and cognitive status since changes in transcription are related to age-associated spatial learning impairments (Burger et al., 2007; Haberman et al., 2011). Several targets have been highlighted including immediate early genes, as well as transthyretin, quinone reductase 2, and prodynorphin (Rowe et al., 2007; Benoit et al., 2011). In addition, dysregulation of epigenetic controls during aging (Penner et al., 2010) could alter the expression of genes involved in memory formation.

An interesting hypothesis to explain age-associated cognitive deficits is the inability to encode new information because of aberrant neuronal networks (Wilson et al., 2006). Neurogenesis has been reported in the adult hippocampus and could be involved in consolidation of new memories. The number of adult progenitor and neural stem cells decline with age (Villeda et al., 2011). Moreover, abnormal differentiation of newborn granule cells have been linked to age-related memory impairments in Agouti rats (Nyffeler et al., 2010). Exercise prevents cognitive deficits by increasing neurogenesis and decreasing apoptosis in the old hippocampus (Kim et al., 2010a). Surprisingly, greater hippocampal neurogenesis has been correlated to memory deficits in old Long-Evans rats (Bizon and Gallagher, 2005). This intriguing observation could either suggest impaired differentiation processes or underlying high cellular stress. Indeed, inflammatory pathways become hyperactivated with age and dysfunctions of the immune system promote neurodegeneration (Lucin and Wyss-Coray, 2009; von Bernhardi et al., 2010). Higher neurogenesis could counteract this phenomenon in the old memory-impaired Long-Evans rat hippocampus. To support this hypothesis, preserved neuron number, total number of synapses, and synaptic proteins have been previously reported in the hippocampus of this animal model (Rapp and Gallagher, 1996; Nicolle et al., 1999, Geinisman et al., 2004). On the other hand, an alteration in post-synaptic densities (PSD) protein expression (Nyffeler et al., 2007) and a reduction in PSD area have been associated to memory impairments in aged LongEvans rats (Nicholson et al., 2004). Refined cellular and molecular mechanisms could lead to a successful cognitive aging and facilitate the maintenance of memory capacities despite aging.

\section{THE BIOCHEMISTRY BEHIND MEMORY: GLUTAMATE RECEPTORS AND SYNAPTIC PLASTICITY}

The formation of new memory traces involves complex networks of neurons in various brain areas. The hippocampus plays a central role in working memory and short-term cognition while cortices store and organize souvenirs following consolidation (Frankland and Bontempi, 2005). While spatial memory is highly dependent on the hippocampus, novel object recognition, and reference memory, cognition processes also affected by aging, involve perirhinal cortex (Burke et al., 2010). Acquisition of a reference memory could be independent of the hippocampus, for example, acquisition of fear conditioning may solely depend on the amygdala, although it may be rendered hippocampal-dependent through manipulation of experimental parameters. The adaptative mechanisms involved require to strengthen or weaken interconnections of neuronal networks known as synaptic plasticity. The biochemistry of synaptic plasticity related to learning and memory has been extensively studied over the last few decades (Baudry et al., 2011). The excitatory neurotransmitter glutamate and its receptors are closely involved in those processes especially for hippocampusdependent spatial memory (Lee and Silva, 2009). Glutamate receptors are present on the membrane of both neurons and glial cells and can be classified into two distinct groups: ionotropic and metabotropic. The ionotropic glutamate receptors family are ion channels activated by glutamatergic agonists and include the 2-amino-3-hydroxy-5-methyl-isoxaole-4-propinate (AMPA) and $\mathrm{N}$-methyl-D-aspartate (NMDA) receptor subtypes (Baudry et al., 2011). The stimulation of AMPA and NMDA receptors induces synaptic plasticity leading to a long-term potentiation (LTP), a form of long-lasting enhancement in signal transmission (Lee and Silva, 2009; Baudry et al., 2011). Those receptors allow $\mathrm{Ca}^{2+}$ ions to enter into the cell, activating several intracellular signaling pathways, receptor trafficking, gene expression, and LTP production (Lee and Silva, 2009; Baudry et al., 2011). Changes in $\mathrm{Ca}^{2+}$ homeostasis have been associated with age-related memory impairments (Burke and Barnes, 2010). In fact, the induction and maintenance of LTP is compromised during aging as reported by several groups (Barnes, 2003; Kumar, 2011). In the Long-Evans rat model, cognitive performances of aged memory-unimpaired animals have been strongly correlated with the magnitude of NMDAindependent LTP (Boric et al., 2008). While young rats seem to rely on NMDA-LTP to build new memories, aged rats use different mechanisms (Figure 1). One reason behind this intriguing phenomenon could be the decrease in ionotropic receptor subunits generally occurring with age (Zhao et al., 2009). The Lou/C/Jall rat strain, however, is an exception to this rule; characterized by an incredible lifespan, absence of obesity, and of various severe
Hippocampus-dependent memory formation in adult brain

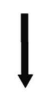

Glutamate receptors-mediated synaptic plasticity

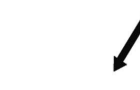
dependent LTP

$$
\begin{aligned}
& \text { NMDA receptor- } \\
& \text { dependent LTD }
\end{aligned}
$$

NMDA receptor-
Successful cognitive aging

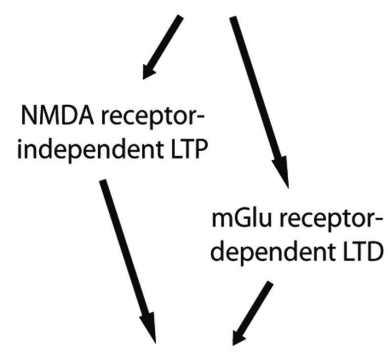

FIGURE 1 | Memory formation and synaptic plasticity in adult versus aged rat brain. Young and adult rats strengthen or weakened their neuronal networks interconnections using various adaptative mechanisms including NMDA receptor-dependent long-term potentiation (LTP) and long-term depression (LTD). On the other hand, successful cognitive aging has been associated with NMDA-independent LTP and mGluR-dependent LTD in memory-unimpaired Long-Evans aged rats. 
pathologies related to aging (Alliot et al., 2002), these animals maintain high cognitive abilities, ionotropic glutamate receptor levels, excitatory postsynaptic currents (EPSC) and LTP despite aging (Kollen et al., 2010).

Long-term depression (LTD), another form of synaptic plasticity has been closely related to memory formation (Ge et al., 2010). LTD has not been investigated as much as LTP in this context but mechanisms behind LTD-associated synaptic plasticity are starting to be unraveled. Contrary to LTP, LTD reduces the efficacy of neuronal synapses in several areas of the brain including the hippocampus (Collingridge et al., 2010). LTD could be important to develop effective neuronal network connections, to facilitate the generation of spatial cognitive maps, and to erase old memory traces (Kemp and Manahan-Vaughan, 2007; Malleret et al., 2010). Prolonged stimulation of NMDA receptors reduces the density of receptors in the PSD, leading to LTD (Mulkey and Malenka, 1992; Collingridge et al., 2010). The activation of Gprotein-coupled metabotropic glutamate receptors (mGluR) can also induce LTD (Palmer et al., 1997; Bellone et al., 2008). Interestingly, NMDA receptor-independent LTD has been correlated with successful cognitive aging in Long-Evans rats (Lee et al., 2005).

\section{GROUP 1 METABOTROPIC GLUTAMATE RECEPTORS AND SUCCESSFUL AGING}

Cloning of the first mGluR subtype was realized in the early 1990s (Masu et al., 1991). Eight mGluR have since been identified and divided into three groups: group 1 with mGluR1 and mGluR5, group 2 includes mGluR2 and mGluR3, and finally group 3 with mGluR4, mGluR6, mGluR7, and mGluR8 (Nicoletti et al., 2011). LTD can be induced by applying group 1 specific agonists such as 3,5-dihydroxyphenylglycine (DHPG; Palmer et al., 1997). In the context of this review, we will focus on this group even if antagonism of pre-synaptic group 2 mGluRs can modulate LTD and spatial memory (Altinbilek and Manahan-Vaughan, 2009).

mGlul receptors have been associated with the post-synaptic specialization of excitatory synapses and are concentrated in perisynaptic and extrasynaptic areas (Nicoletti et al., 2011). On the other hand, mGluR5 functionally interact with NMDA receptors in the PSD (Tu et al., 1999; Collett and Collingridge, 2004). mGlu5 receptors are abundant in the hippocampus and cerebral cortex in the adult brain (Romano et al., 1996). Mice lacking mGluR5 show impaired learning and reduced LTP in the CA1 region (Lu et al., 1997). The EPSC of AMPA receptors are normal in these mice while the LTP component related to NMDA receptors is completely lost (Jia et al., 1998). This deficit can be rescued by protein kinase C (PKC) stimulation (Jia et al., 1998). mGluR5 potential role in learning and memory was confirmed by gene targeting (Jia et al., 2001). mGluR5 knock-out (KO) mice show mild cognitive deficits in the MWM task whereas memory impairments were significant for discrimination reversal, which involves inhibitory learning processes necessary to extinct old memories (Xu et al., 2009). Accordingly, we reported an increase in mGluR5 protein levels in the PSD of aged memory-unimpaired Long-Evans rats and inhibitory learning was highly conserved in this group in comparison with old memory-impaired animals (Menard and Quirion, 2012). These behavioral and biochemical data are in agreement with higher mGluR-LTD previously reported in aged memory-unimpaired Long-Evans rats (Lee et al., 2005). Aging is associated with pattern separation deficits: old Fischer 344 rats show age-dependent object recognition memory impairment (Burke et al., 2010). Novel object recognition involves perirhinal cortex but we speculate that the confusion between old versus new platform positions reported for aged memory-impaired Long-Evans rats in the hippocampus-dependent MWM task could be explained by alterations in synaptic processes modulated by mGluR. Indeed, the stimulation of group $1 \mathrm{mGluR}$ could act like a molecular switch to facilitate synaptic plasticity (Bortolotto et al., 2005) and to regulate late phases of both LTP and LTD in the hippocampus (Neyman and Manahan-Vaughan, 2008). Daily application of the mGluR5 antagonist, 2-methyl-6-(phenylethynyl) pyridine (MPEP), impaired both working and reference memory in Wistar rats while only working memory is affected in hooded Lister rats (Manahan-Vaughan and Braunewell, 2005). This difference could be related to higher brain levels of mGluR5 in Wistar rats (Manahan-Vaughan and Braunewell, 2005). Prolonged pharmacological blockade of mGluR5 by MPEP reduces mGluR1 expression, impairs LTP as well as spatial memory, and suppresses theta and gamma oscillations in the dentate gyrus (Bikbaev et al., 2008). Increased neurogenesis in aged memory-impaired LongEvans rat as mentioned previously could be related to disrupted neuronal networks modulated by mGlu 5 receptors. Fear memory, gustatory memory, and social interaction could also be modulated by mGluR5 (Simonyi et al., 2010). Interestingly, addiction is often characterized by persistent cognitive deficits and Long-Evans rats treated with methamphetamine show reference memory impairments (Reichel et al., 2011). This deficit can be reversed by treatment with an allosteric modulator of mGlu5 receptors (Reichel et al., 2011). Memory processes are highly influenced by stress and various psychosocial factors (Kremen et al., 2012) and could influence group $1 \mathrm{mGluR}$ interactions with its effectors and scaffolding Homer proteins (Tronson et al., 2010).

\section{MODULATION OF GROUP 1 METABOTROPIC GLUTAMATE RECEPTOR FUNCTION}

The Homer proteins family consists of dendritic auxiliary proteins that contain a single PDZ domain and bind to the carboxy (C)-terminal domain of group 1 mGluR (Brakeman et al., 1997), acting as both scaffolding and transduction molecules (Fagni et al., 2002). Homer proteins are widely expressed in the central nervous system as well as in peripheral tissues and are predominantly localized at the PSD of mammalian neurons (Shiraishi-Yamaguchi and Furuichi, 2007). Consequence of alternative splicing, several variants of Homer products exist and are classified as either short (Homer 1a) or long (Homer 1b/c, Homer 2, and Homer 3) forms (Fagni et al., 2002). Long isoforms of Homer are constitutively expressed (Xiao et al., 1998) and form synaptic clusters with other proteins of the PSD, facilitating signal transduction, and interactions with plasma membrane receptors (Shiraishi-Yamaguchi and Furuichi, 2007). NMDA receptors for example are directly associated to mGluR via the interaction of Homer with Shank and PSD-95 protein complexes (Tu et al., 1999). Homer 1 proteins also regulate mGluR trafficking in the cell and therefore downstream signaling resulting from neuronal activity (Ango et al., 2002; Duncan et al., 2005). While Homer 1c increases cell surface expression 
of mGluR1 in the plasma membrane (Ciruela et al., 2000), Homer 1 b retains mGluR5 in the endoplasmic reticulum (Roche et al., 1999). On the other hand, Homer 1a is an immediate early gene expressed following neuronal activity (Tu et al., 1998). When bound to group $1 \mathrm{mGluR}$, Homer 1a disrupts the protein clusters by competitive binding (Xiao et al., 1998; Shiraishi-Yamaguchi and Furuichi, 2007). Homer 1a acts as a dominant negative modulator by reducing mGluR5 coupling with its signaling effectors (Kammermeier and Worley, 2007). It may also inhibit NMDA currents following disruption of the Homer-Shank complex (Bertaso et al., 2010). Conversely, a prolonged activation of NMDA receptors increases $\mathrm{Ca}^{2+}$ entry in neuronal cells, activating multiple enzymes including proteases such as calpains (Zadran et al., 2010). Calpains cleave mGluR1 C-terminal domain and maintain their ability to release cytosolic $\mathrm{Ca}^{2+}$ from intracellular stores resulting in excitotoxicity and eventually neuronal degeneration (Xu et al., 2007). Interestingly, the ratio of Homer 1a to Homer $1 \mathrm{~b}$ can modulate mGluR-mediated plasticity of AMPA receptor transmission in optic cells following visual stimulation (van Keuren-Jensen and Cline, 2006). mGluR receptors and Homer proteins could also be involved in synaptogenesis (Xiao et al., 2000) and actively modulate synaptic plasticity in learning and memory. Thus, an overexpression of Homer la in the dorsal hippocampus may impair spatial working memory (Klugmann et al., 2005; Celikel et al., 2007).

Another intriguing hypothesis is about the involvement of mGlu receptors in homeostatic scaling (Hu et al., 2010). This form of non-Hebbian plasticity reinforces synaptic strength or activity of neuronal networks; the strength of synapses either scaled up by diminishing the surrounding network activity or scaled down by increasing this same network (Turrigiano and Nelson, 2000). An increment or reduction of AMPA receptors at excitatory synapses is an effective common form of homeostatic scaling (O'Brien et al., 1998; Turrigiano and Nelson, 2000). The activation of group 1 mGluR and the synthesis of Homer la regulate the expression of AMPA receptors. The level of Homer 1a is up-regulated after neuronal activity followed by agonist-independent signaling of group $1 \mathrm{mGluR}$, which reduces the tyrosine phosphorylation of GluR2 AMPA receptor subunit, subsequently scaling down the expression of those plasma membrane receptors (Hu et al., 2010).

Norbin, a key neuronal regulator promoting neurite outgrowth, synaptic plasticity, and LTP, also interacts with mGluR5 (Wang et al., 2010). This neuron-specific protein not only physically interacts with mGluR5 but increases the cell surface localization of the receptor and subsequently mGluR5 signaling (Wang et al., 2009). Similar to mGluR5 KO mice, Norbin KO animals show impaired synaptic plasticity and altered behaviors (Wang et al., 2009).

Group 1 mGluR regulate the activity of several kinases. However, their direct phosphorylation affects both receptor signaling and trafficking (Kim et al., 2008; Mao et al., 2008). The stimulation of both mGluR1 and mGluR5 triggers the release of $\mathrm{Ca}^{2+}$ intracellular stores. While mGluR1 activation by glutamate induces a single peak of $\mathrm{Ca}^{2+}$ release, mGluR5 releases $\mathrm{Ca}^{2+}$ by oscillations (Kawabata et al., 1996). This mechanism is made possible by the phosphorylation by PKC at residue threonine 840 of mGluR5 (Kawabata et al., 1996). On the other hand, the phosphorylation of serine 901 by PKC inhibits mGluR5 binding to calmodulin, decreasing its surface expression (Lee et al., 2008). Moreover, PKC can phosphorylate mGluR5 at multiple sites, quickly desensitizing the receptor (Gereau and Heinemann, 1998). Cyclin-dependent kinase 5, a proline-directed serine/threonine kinase can also phosphorylate the Homer binding domain of both mGluR1 and mGluR5, enhancing the interaction (Orlando et al., 2009).

\section{SIGNALING PATHWAYS RELATED TO GROUP 1 MGLUR ACTIVATION}

Ionotropic and mGluRs can act synergistically to induce LTP and to modulate synaptic plasticity. For example, the activation of both receptors seems to be required for the stimulation of the PKCgamma $(\gamma)$ isoform (Codazzi et al., 2006). Spatial experience and training increases PKC $\gamma$ expression (Nithianantharajah and Murphy, 2009), which is subsequently translocated from the cytoplasm to the membrane and is co-localized with mGluR5 in the CA1 hippocampus region after receptor activation (Liu et al., 2008). Individual differences in cognitive status observed in aged Long-Evans rats have been linked to this kinase (Colombo et al., 1997; Colombo and Gallagher, 2002). Moreover, the activation of PKC in small groups of hippocampal or cortical neurons in 2-yearold rats improved MWM performance, confirming the important role of this kinase in learning and spatial memory (Zhang et al., 2009). PKC enzyme activators have been proposed to enhance cognitive performances and may prevent or reduce dementia and memory deficits associated to age-related neurodegenerative diseases (Sun and Alkon, 2010).

Protein kinase $\mathrm{C}$ is not the only group of kinases regulated by ionotropic and mGluRs function; NMDA and mGluR5 receptors also interact to regulate the phosphorylation of the extracellular signal-regulated protein kinase (ERK; Yang et al., 2004). This synergy is related to PSD-95 and Homer $1 \mathrm{~b} / \mathrm{c}$ interaction and is independent of $\mathrm{Ca}^{2+}$ influx. The activation of ERK leads to the facilitation of c-fos expression, an immediate early gene produced following neuronal activity (Yang et al., 2004). Accordingly, ERK signaling is required to establish mGluR-dependent LTD in the hippocampus (Gallagher et al., 2004) and it diminished with age (Williams et al., 2006). The inhibition of the ERK signaling pathway does not impair MWM learning acquisition but prevent longterm spatial memory formation (Blum et al., 1999). Thus, agerelated changes in ERK expression could be involved in cognitive decline and lower mGluR function may exacerbate this deficit.

The stimulation of group $1 \mathrm{mGluR}$ with DHPG increases that of another central kinase for multiple signaling pathways: the mammalian target of rapamycin (mTOR; Page et al., 2006). The inhibition of mTOR prevents mGluR-LTD induced by DHPG (Hou and Klann, 2004) and our group has recently shown a strong positive correlation between successful cognitive aging in LongEvans rats and downstream signaling pathways of group $1 \mathrm{mGluR}$ activation including the mTOR cascade (Menard and Quirion, 2012). This serine/threonine protein kinase modulates the activity of several translation regulatory factors including p70S6 kinase (Page et al., 2006). An increased phosphorylation of the S6 complex has been associated to mGluR-LTD (Antion et al., 2008). Moreover, the activation of NMDA and mGluRs has been shown to regulate dendritic synthesis via mTOR activity (Gong et al., 2006). Hence, mTOR-dependent translational control is critical not only 
for spatial memory. Stability of long-term fear memory is compromised if mTOR activation and phosphorylation of p70S6 kinase is altered (Parsons et al., 2006). In addition, mTOR could contribute to alcohol abuse and addiction by up-regulating AMPA GluR1 subtype and Homer proteins in the nucleus accumbens (Neasta et al., 2010). Dysfunctions of downstream cell signaling events linked to mGlu receptors could thus impair multiple aspects of the brain functions (Figure 2).

Gene expression has often been targeted to explain memory deficits related to aging (Alberini, 2009; Benoit et al., 2011). Dysregulation of the phosphorylation of the cAMP response elementbinding (CREB), a cellular transcription factor modulating the transcription of many genes, has been reported in the hippocampus of aged rats after fear conditioning training (Monti et al., 2005). CREB protein level is also lower in old memory-impaired rats compared to young animals (Brightwell et al., 2004). CREBmediated transcription could stabilize the establishment and reactivation of spatial memory (Kim et al., 2011). Reduced synthesis of several proteins related to LTP and among proteins regulated by $\mathrm{CREB}$, the activity-regulated cytoskeleton-associated protein (Arc, also known as Arg 3.1) has been correlated to aged-related cognitive impairments (Monti et al., 2005; Menard and Quirion, 2012). Conversely, calcineurin, a phosphatase modulating CREB activation, is highly expressed in the hippocampus of aged rats (Monti et al., 2005) and negatively correlated to LTP and memory (Malleret et al., 2001). Recently, our group reported that lower hippocampal CREB phosphorylation levels in old memory-impaired Long-Evans rats following MWM training could lead to reduced Arc expression and cognitive deficits (Menard and Quirion, 2012).

Following neuronal activity, Arc encoding mRNA is quickly transported to dendrites and then translated, making it a strong candidate for synaptic plasticity underlying LTP and LTD induction and maintenance (Bramham et al., 2008; Shepherd and Bear, 2011). Homeostatic scaling has recently been associated to Arc expression (Beique et al., 2011) and our group proposed that successful cognitive aging is linked to high levels of Arc expression in hippocampal dendrites of aged rats following mGluR stimulation by training (Menard and Quirion, 2012). Interestingly, activityinduced Notch signaling pathway in neurons also requires Arc expression (Alberi et al., 2011). Notch plays an important role in cell fate specification and could contribute to memory formation. Indeed, the activation of Notch signaling pathway prevents neural

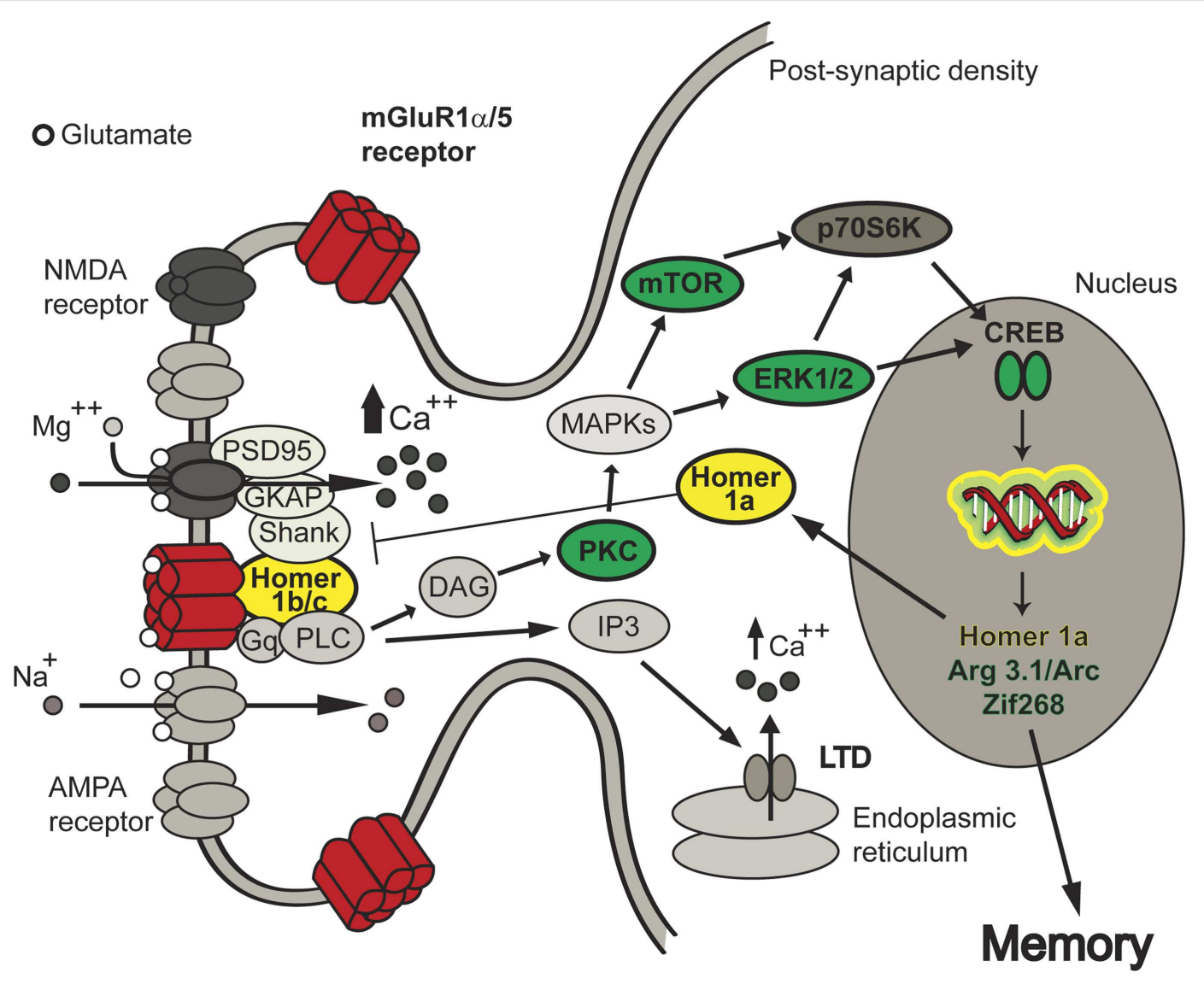

FIGURE 2 | Signaling pathways involved in mGluR-LTD and hippocampus-dependent spatial memory. Group 1 metabotropic glutamate receptors ( $m G l u R 1 \alpha / 5)$ are bound to ionotropic glutamate receptors by multiple scaffolding proteins (Homer 1 b/c, Shank, GKAP, PSD-95). Following mGluR stimulation, several protein kinases including PKC, ERK1/2, mTOR, and CREB become activated and induce the expression of various immediate early genes like Homer 1a, Arg3.1/Arc, and Zif268. Homer 1a is released in the cytosol and translocated to the plasma membrane uncoupling the $\mathrm{mGlu}$ receptors from its signaling effectors. These signaling pathways have been associated with multiples brain functions and could be critical to maintain cognition during normal aging. 
stem cells depletion and maintains tight control of neurogenesis in the adult brain (Imayoshi et al., 2010). Accordingly, reduced Arc and Notch signaling could be closely related to memory impairments associated with aging.

Another immediate early gene, Zif268, is required for the late phases of LTP and the expression of long-term memories. Indeed, LTP is lost after $24 \mathrm{~h}$ in mutant mice (Jones et al., 2001; Bozon et al., 2002). Zif268 is constitutively expressed in the rat brain with high levels seen in the hippocampal CA1 region (Alberini, 2009). While the role of Arc in synaptic plasticity seems to cover several phases of memory formation, the expression of Zif268 is apparently critical for specific steps like the persistence of LTP and the reactivation of old memories (Bozon et al., 2003). In our animal model of successful cognitive aging, we reported no significant changes in Zif268 levels (Menard and Quirion, 2012). While the role of Zif268 in associative memory is still debated, conflicting results have also been reported regarding synaptic plasticity (Alberini, 2009).

Group 1 mGluR signaling could be crucial for cognition during aging but it has also been related to pathological conditions like Fragile X syndrome (FXS) and Alzheimer's disease (AD). Results published on animal models of those diseases and clinical trials conducted with patients will thus help to understand the processes involved in the aging of the brain.

\section{mGIUR RECEPTOR MALFUNCTION AND FRAGILE $X$ SYNDROME}

Group 1 mGluRs have been implicated in the development of the FXS (Dolen et al., 2007). FXS is the most common inherited cause of mental retardation and is likely related to autism (Dolen and Bear, 2008). A mutation blocks the FMR1 gene transcription which encodes the Fragile X mental retardation protein (FMRP; Pieretti et al., 1991). This RNA-binding protein acts predominantly as a negative regulator of protein synthesis and controls the dynamic translation of several mRNA involved in learning and memory including Arc (Park et al., 2008; Darnell et al., 2011). FMRP regulates several mRNA localization, stability, and translational efficiency in dendrites following mGluR stimulation (Zukin et al., 2009). Multiple symptoms are associated with FXS including moderate to severe mental retardation, behavioral problems, dysmorphic features, and increased susceptibility to seizures (Dolen and Bear, 2008). NMDA-dependent LTP is reduced in the anterior piriform cortex of adult and aged FXS mice (Larson et al., 2005; Gocel and Larson, 2012). On the other hand, synaptic plasticity related to LTP and NMDA-dependent LTD is intact in FMRP KO mice hippocampus (Godfraind et al., 1996). Accordingly, protein levels of AMPA and NMDA glutamate receptor subtypes are unaltered as well (Giuffrida et al., 2005). In contrast, mGluR5 level is specifically decreased in the PSD, suggesting reduced protein synthesis induced by the stimulation of group $1 \mathrm{mGluR}$ (Giuffrida et al., 2005). This alteration could explain the cognitive impairments observed for inhibitory learning and reverse memory in the MWM task (Godfraind et al., 1996). Unfortunately, this last finding has never been replicated by other groups. Conversely, mGluR-LTD is enhanced in these FMRP mutant mice (Huber et al., 2002). Whereas mGluRs seem to play an important role in successful cognitive aging (Menard and Quirion, 2012), young animals favor NMDA-dependent synaptic plasticity processes (Lee et al., 2005). Hence, excessive mGluR-LTD in adult FMR1 KO mice and FXS patients could dysregulate synaptic plasticity and lead to memory deficits (Luscher and Huber, 2010; Figure 3).

The stimulation of group $1 \mathrm{mGluR}$ with the specific agonist DHPG normally induces FMR protein translation in dendrites (Weiler et al., 1997). In FMR1 KO mice, the lack of this protein synthesis suppressor may unbalance cellular mechanisms and exaggerate mGluR-dependent signaling (Dolen and Bear, 2008). Hence, excessive protein synthesis downstream of mGluR activation could induce the complex synaptic pathophysiology seen in FXS (Bear et al., 2004). In fact, mRNA translation seems to be hypersensitive to basal ERK activation in the absence of FMRP and contributes to seizure susceptibility (Osterweil et al., 2010). Phosphoinositide 3-kinase (PI3K), an enzyme downstream of several cell surface receptors including group $1 \mathrm{mGluR}$, becomes excessively active and insensitive to mGluR stimulation in the absence of FMRP (Gross et al., 2010). In contrast, mGluR-simulated protein translation initiated by the mTOR pathway is lost (Ronesi and Huber, 2008). These alterations are probably linked, at least in part, to disrupted Homer scaffolds. Indeed, in the FMR1 KO mice brain, mGluR5 is associated more with Homer 1a stimulating agonist-independent signaling pathways than long Homer isoforms (Ronesi et al., 2012). Genetic deletion of Homer la rescues mGluR signaling, enhances protein translation and reduces the severity and incidence of seizures in this FXS animal model (Ronesi et al., 2012). On the other hand, Homer 1a deletion did not improve abnormal mGluR-LTD or DHPG-induced Arc synthesis deficit, supporting an essential role of FMR protein in these processes (Ronesi et al., 2012). In accordance, in FMR1 KO mice, mGluR-LTD formation does not require the acute stimulation of protein synthesis which is probably related to the constitutive overexpression of proteins implicated in LTD formation and maintenance to compensate for the lack of FMR1 (Hou et al., 2006; Nosyreva and Huber, 2006). Homeostatic plasticity is affected as well in this FXS animal model with a decrease in the expression of AMPA surface receptors (Nosyreva and Huber, 2006). The magnitude of LTP can be enhanced following group $1 \mathrm{mGluR}$ stimulation; this facilitation is known as LTP priming (Cohen and Abraham, 1996). In FMR1 KO mice, LTP priming is reduced by mGluR decoupling from protein synthesis (Auerbach and Bear, 2010).

The first demonstration of mGluR modulation rescuing phenotypes in FXS animal models was attained by pharmacologically rescuing social interaction and memory impairments in the Drosophila fly model (McBride et al., 2005). Age-dependent cognitive deficits can also be rescued by mGluR antagonists in this animal model (Choi et al., 2010). Decreased mGluR5 signaling could rescue several features in the FXS mutant mice as well including dendritic spine abnormalities, ocular dominance plasticity, accelerated body growth, open field center behavior, and seizure susceptibility (Yan et al., 2005; Dolen et al., 2007). Synaptic plasticity deficits including enhanced mGluR-LTD can be reversed by chronic in vivo treatment with group $2 \mathrm{mGluR}$ antagonists in these mice (Choi et al., 2011). Profound cognitive impairments are observed in human suffering from FXS. Interestingly, alterations in inhibitory avoidance extinction can be reversed in FMR1 KO mice by reducing mGluR-LTD with a $50 \%$ reduction in mGluR5 


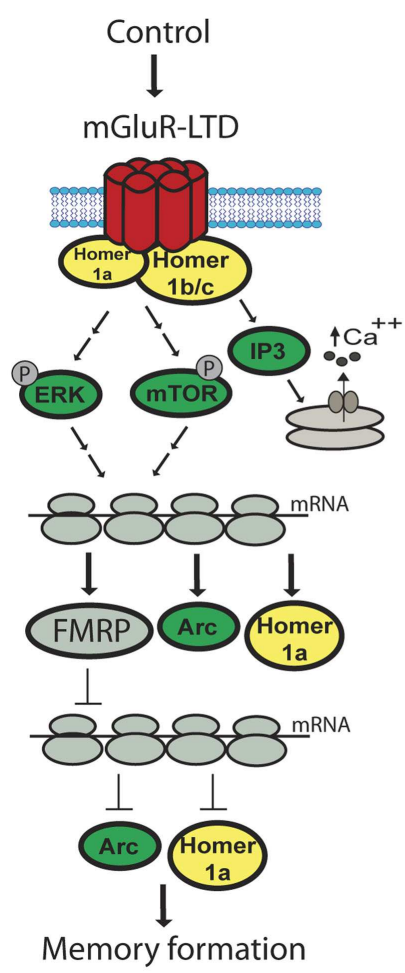

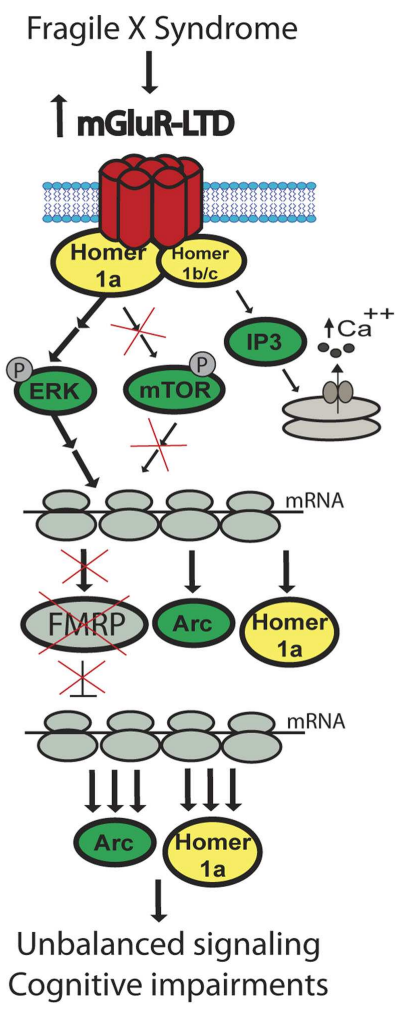

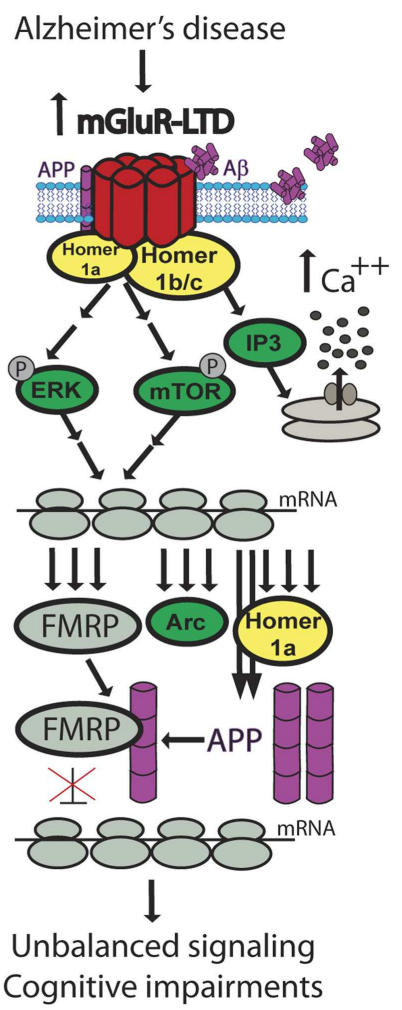

FIGURE 3 | Comparison of mGluR-related signaling pathways activation in successful cognitive aging, Fragile $X$ syndrome, and Alzheimer's disease. Activation of group $1 \mathrm{mGluR}$ mediates $\mathrm{Ca}^{+2}$ release from intracellular stores and protein translation through the activation of several kinases including ERK and mTOR. Once translated, FMRP proteins act as a negative regulator of protein synthesis and reduce LTD-related proteins levels and IEG expression. A good balance of these mechanisms leads to memory formation in the aged brain. Excessive mGluR-LTD has been linked to the Fragile $X$ syndrome. While ERK activation is enhanced, protein synthesis related to the mTOR pathway is lost. Moreover, mGluR5 is associated more with Homer 1a stimulating agonist-independent signaling pathways. Without FMRP to decrease the protein translation, LTD-related proteins are overexpressed and memory is impaired. Excessive mGluR-LTD has also been reported in Alzheimer's disease. A $\beta$ oligomers clusters mGluRs on the plasma membrane promoting $\mathrm{Ca}^{2+}$ signaling and release from intracellular stores. Stimulation of group $1 \mathrm{mGluR}$ also increases APP translation. FMRP can bind to APP possibly altering the protein synthesis negative control and creating memory deficits. expression (Dolen et al., 2007). Since reducing group $1 \mathrm{mGluR}$ function improves multiple phenotypes in animal models of FXS, clinical trials based on mGluR5 inhibition are currently underway (Krueger and Bear, 2011) and the first results seem promising (Jacquemont et al., 2011). However, considering the potential role of these receptors in successful cognitive aging, potential side effects on memory processes should be carefully monitored.

\section{ALZHEIMER'S DISEASE AND GROUP 1 mGIUR FUNCTION}

A possible link between FXS and AD has been proposed since FMR protein binds to the amyloid precursor protein (APP; Sokol et al., 2011), APP is overexpressed in the FMR1 KO mice brain (D'Agata et al., 2002) and the group 1 mGluR agonist DHPG increases APP translation (Westmark and Malter, 2007; Sokol et al., 2011). Moreover, a strong genetic interaction has been identified between Drosophila FMRP gene and presenilin, a protein mutated in the familial form of AD (McBride et al., 2010). Reduction of presenilin function in this animal model induces age-related cognitive deficits that can be prevented by mGluR antagonists or genetic reduction (McBride et al., 2010). AD is the most common form of dementia and generally diagnosed in patients over 65 years of age.
First described in 1906, this neurodegenerative disorder is characterized by mood changes, language dysfunctions, progressive cognitive deficits, and brain atrophy (Gauthier and Poirier, 2008; Pasic et al., 2011). The exact causes of AD are not well understood but include various hallmarks such as senile plaques and neurofibrillary tangles. These markers are used at the autopsy to confirm the diagnosis (Gauthier and Poirier, 2008; Pasic et al., 2011). Senile plaques consist of extracellular deposits of amyloid-beta $(\mathrm{A} \beta)$ proteins often surrounded by active microglia (Kellner et al., 2009). $A \beta$ plaques tend to aggregate and become neurotoxic for the neighboring cells. In contrast, neurofibrillary tangles are made of hyperphosphorylated tau proteins and accumulate intracellularly leading to synaptic dysfunction (Gauthier and Poirier, 2008; Pasic et al., 2011). Since the stimulation of group $1 \mathrm{mGluR}$ releases $\mathrm{Ca}^{2+}$ from intracellular stores, it can also facilitate the hyperphosphorylation of tau by up-regulating protein kinase activities (Tsai et al., 2005; Figure 3). Interestingly, the stimulation of group $1 \mathrm{mGluR}$ with DHPG induces a rapid accumulation of APP c-terminal fragments (CTF) in synaptoneurosomes obtained from the brains of the CRND8 Alzheimer mouse model whereas group $2 \mathrm{mGluR}$ activation triggers the production and release of $A \beta$ (Kim et al., 
2010b). In neuronal cultures, the selective activation of mGlu2 receptors amplify $A \beta$ toxicity while the co-activation of the same receptors with mGluR3 is neuroprotective (Caraci et al., 2011). Significant mGlu2 receptor losses have been reported to occur in the enthorinal cortex in AD brains (Richards et al., 2010). The discrete localization of group $1 \mathrm{mGluR}$ has not yet been investigated in detail in the human brain but its signaling is down-regulated in the frontal cortex of $\mathrm{AD}$ subjects and worsens with the progression of the disease (Albasanz et al., 2005). In rat hippocampal neurons, $\mathrm{A} \beta$ oligomers cluster at the cell surface and overstabilize mGluR5 in a time dependent manner, promoting increased $\mathrm{Ca}^{2+}$ signaling, synaptotoxicity, and eventually synapse deterioration (Renner et al., 2010). Concomitantly, soluble A $\beta$ disrupts Homer $1 \mathrm{~b}$ and Shank scaffolding with metabotropic and ionotropic glutamate receptors, respectively, shrinking the PSD and affecting downstream signaling pathways (Roselli et al., 2009). The activation of mGluR5 increases the translocation of receptors from extrasynaptic sites to the PSD, then Homer stabilizes the receptors in clusters in the plasma membrane (Serge et al., 2002). Both receptors and mGluR-Homer clusters are highly dynamic in their movements and this mobility is affected by $\mathrm{A} \beta$ leading to unbalanced mGluRmediated signaling, protein translation, synaptic plasticity and eventually memory deficits. Thus, misfolded proteins in AD may not only induce pathology-related synaptic defects but also block the maintenance of successful cognitive aging processes. Recently, an enhanced endocannabinoid signaling has been reported in the

\section{REFERENCES}

Albasanz, J. L., Dalfo, E., Ferrer, I., and Martin, M. (2005). Impaired metabotropic glutamate receptor/phospholipase $\mathrm{C}$ signaling pathway in the cerebral cortex in Alzheimer's disease and dementia with Lewy bodies correlates with stage of Alzheimer's-diseaserelated changes. Neurobiol. Dis. 20, 685-693.

Alberi, L., Liu, S., Wang, Y., Badie, R., Smith-Hicks, C., Wu, J., et al. (2011). Activity-induced Notch signaling in neurons requires Arc/Arg3.1 and is essential for synaptic plasticity in hippocampal networks. Neuron 69, 437-444.

Alberini, C. M. (2009). Transcription factors in long-term memory and synaptic plasticity. Physiol. Rev. 89, 121-145.

Alliot, J., Boghossian, S., Jourdan, D., Veyrat-Durebex, C., Pickering, G., Meynial-Denis, D., et al. (2002). The $\mathrm{LOU} / \mathrm{c} / \mathrm{jall}$ rat as an animal model of healthy aging? J. Gerontol. A Biol. Sci. Med. Sci. 57, B312-B320.

Altinbilek, B., and Manahan-Vaughan, D. (2009). A specific role for group II metabotropic glutamate receptors in hippocampal long-term depression and spatial memory. Neuroscience 158, 149-158.

Ango, F., Robbe, D., Tu, J. C., Xiao, B., Worley, P. F., Pin, J. P., et al.
(2002). Homer-dependent cell surface expression of metabotropic glutamate receptor type 5 in neurons. Mol. Cell. Neurosci. 20, 323-329.

Antion, M. D., Hou, L., Wong, H., Hoeffer, C. A., and Klann, E. (2008). mGluR-dependent longterm depression is associated with increased phosphorylation of S6 and synthesis of elongation factor 1A but remains expressed in S6K-deficient mice. Mol. Cell. Biol. 28, 2996-3007.

Aubert, I., Rowe, W., Meaney, M. J., Gauthier, S., and Quirion, R. (1995). Cholinergic markers in aged cognitively impaired Long-Evans rats. Neuroscience 67, 277-292.

Auclair, A. L., Besnard, J., NewmanTancredi, A., and Depoortere, R. (2009). The five choice serial reaction time task: comparison between Sprague-Dawley and Long-Evans rats on acquisition of task, and sensitivity to phencyclidine. Pharmacol. Biochem. Behav. 92, 363-369.

Auerbach, B. D., and Bear, M. F. (2010). Loss of the fragile X mental retardation protein decouples metabotropic glutamate receptor dependent priming of long-term potentiation from protein synthesis. J. Neurophysiol. 104, 1047-1051.

Barnes, C. A. (2003). Long-term potentiation and the ageing brain. Philos. Trans. R. Soc. Lond. B Biol. Sci. 358, 765-772.

hippocampi of patients suffering from $\mathrm{AD}$, particularly around senile plaques (Mulder et al., 2011). Robust hippocampal LTD could be induced by activation of the pre-synaptic cannabinoid1 receptors and this form of synaptic plasticity, downstream of NMDA, and mGlu5 receptor activation (Izumi and Zorumski, 2012), could be exacerbated by A $\beta$. Thus, it seems that various neurotransmission systems might be dependent of an intact mGluR function during aging.

\section{CONCLUSION}

After several decades of intense studies on processes involving ionotropic glutamate receptors in the aging brain, their metabotropic counterparts, and particularly post-synaptic group 1 mGluRs are becoming key targets to unravel synaptic plasticity processes underlying learning and memory. mGlu receptors, Homer proteins, and downstream signaling pathways likely all play critical roles in the maintenance of high cognitive abilities in old age. Further studies are thus highly warranted especially considering their apparent role in FXS and possibly AD.

\section{ACKNOWLEDGMENTS}

The authors would like to thank Mira Thakur for editing this manuscript. This research was supported by a grant from the Canadian Institutes of Health Research (CIHR) to Rémi Quirion (Grant \#MOP-8580). Caroline Menard is the recipient of a postdoctoral fellowship from CIHR.

Baudry, M., Bi, X., Gall, C., and Lynch, G. (2011). The biochemistry of memory: the 26 year journey of a 'new and specific hypothesis'. Neurobiol. Learn. Mem. 95, 125-133.

Bear, M. F., Huber, K. M., and Warren, S. T. (2004). The mGluR theory of fragile X mental retardation. Trends Neurosci. 27, 370-377.

Beique, J. C., Na, Y., Kuhl, D., Worley, P. F., and Huganir, R. L. (2011). Arcdependent synapse-specific homeostatic plasticity. Proc. Natl. Acad. Sci. U.S.A. 108, 816-821.

Bellone, C., Luscher, C., and Mameli, M. (2008). Mechanisms of synaptic depression triggered by metabotropic glutamate receptors. Cell Mol. Life Sci. 65, 2913-2923.

Benoit, C. E., Rowe, W. B., Menard, C., Sarret, P., and Quirion, R. (2011). Genomic and proteomic strategies to identify novel targets potentially involved in learning and memory. Trends Pharmacol. Sci. 32, 43-52.

Bertaso, F., Roussignol, G., Worley, P., Bockaert, J., Fagni, L., and Ango, F. (2010). Homerla-dependent crosstalk between NMDA and metabotropic glutamate receptors in mouse neurons. PLoS ONE 5, e9755. doi:10.1371/journal.pone.0009755

Bikbaev, A., Neyman, S., Ngomba, R. T., Conn, P. J., Nicoletti, F., and Manahan-Vaughan, D. (2008). MGluR5 mediates the interaction between late-LTP, network activity, and learning. PLoS ONE 3, e2155. doi:10.1371/journal.pone.0002155

Bizon, J. L., and Gallagher, M. (2005). More is less: neurogenesis and agerelated cognitive decline in LongEvans rats. Sci. Aging Knowledge Environ. 2005, re2.

Blum, S., Moore, A. N., Adams, F., and Dash, P. K. (1999). A mitogenactivated protein kinase cascade in the CA1/CA2 subfield of the dorsal hippocampus is essential for longterm spatial memory. J. Neurosci. 19, 3535-3544.

Boric, K., Munoz, P., Gallagher, M., and Kirkwood, A. (2008). Potential adaptive function for altered longterm potentiation mechanisms in aging hippocampus. J. Neurosci. 28, 8034-8039.

Bortolotto, Z. A., Collett, V. J., Conquet, F., Jia, Z., van der Putten, H., and Collingridge, G. L. (2005). The regulation of hippocampal LTP by the molecular switch, a form of metaplasticity, requires mGlu5 receptors. Neuropharmacology 49(Suppl 1), 13-25.

Bozon, B., Davis, S., and Laroche, S. (2002). Regulated transcription of the immediate-early gene Zif268: mechanisms and gene dosagedependent function in synaptic plasticity and memory formation. Hippocampus $12,570-577$. 
Bozon, B., Davis, S., and Laroche, S. (2003). A requirement for the immediate early gene zif268 in reconsolidation of recognition memory after retrieval. Neuron 40, 695-701.

Brakeman, P. R., Lanahan, A. A., O’Brien, R., Roche, K., Barnes, C. A., Huganir, R. L., et al. (1997). Homer: a protein that selectively binds metabotropic glutamate receptors. Nature 386, 284-288.

Bramham, C. R., Worley, P. F., Moore, M. J., and Guzowski, J. F. (2008). The immediate early gene arc/arg3.1: regulation, mechanisms, and function. J. Neurosci. 28, 11760-11767.

Brightwell, J. J., Gallagher, M., and Colombo, P. J. (2004). Hippocampal CREB1 but not CREB2 is decreased in aged rats with spatial memory impairments. Neurobiol. Learn. Mem. 81, 19-26.

Burger, C., Lopez, M. C., Feller, J. A., Baker, H. V., Muzyczka, N., and Mandel, R. J. (2007). Changes in transcription within the CAl field of the hippocampus are associated with age-related spatial learning impairments. Neurobiol. Learn. Mem. 87, 21-41.

Burke, S. N., and Barnes, C. A. (2010). Senescent synapses and hippocampal circuit dynamics. Trends $\mathrm{Neu}$ rosci. 33, 153-161.

Burke, S. N., Wallace, J. L., Nematollahi, S., Uprety, A. R., and Barnes, C. A. (2010). Pattern separation deficits may contribute to ageassociated recognition impairments. Behav. Neurosci. 124, 559-573.

Caraci, F., Molinaro, G., Battaglia, G., Giuffrida, M. L., Riozzi, B., Traficante, A., et al. (2011). Targeting group II metabotropic glutamate ( $\mathrm{mGlu}$ ) receptors for the treatment of psychosis associated with Alzheimer's disease: selective activation of mGlu2 receptors amplifies beta-amyloid toxicity in cultured neurons, whereas dual activation of mGlu2 and mGlu3 receptors is neuroprotective. Mol. Pharmacol. 79, 618-626.

Celikel, T., Marx, V., Freudenberg, F., Zivkovic, A., Resnik, E., Hasan, M. T., et al. (2007). Select overexpression of homerla in dorsal hippocampus impairs spatial working memory. Front. Neurosci. 1: 97-110. doi:10.3389/neuro.01.1.1.007.2007

Choi, C. H., McBride, S. M., Schoenfeld, B. P., Liebelt, D. A., Ferreiro, D., Ferrick, N. J., et al. (2010). Agedependent cognitive impairment in a Drosophila fragile X model and its pharmacological rescue. Biogerontology 11, 347-362.
Choi, C. H., Schoenfeld, B. P., Bell, A. J., Hinchey, P., Kollaros, M., Gertner, M. J., et al. (2011). Pharmacological reversal of synaptic plasticity deficits in the mouse model of fragile X syndrome by group II mGluR antagonist or lithium treatment. Brain Res. 1380, 106-119.

Ciruela, F., Soloviev, M. M., Chan, W. Y., and McIlhinney, R. A. (2000). Homer-1c/Vesl-1L modulates the cell surface targeting of metabotropic glutamate receptor type lalpha: evidence for an anchoring function. Mol. Cell. Neurosci. 15, 36-50.

Codazzi, F., Di Cesare, A., Chiulli, N., Albanese, A., Meyer, T., Zacchetti, D., et al. (2006). Synergistic control of protein kinase Cgamma activity by ionotropic and metabotropic glutamate receptor inputs in hippocampal neurons. J. Neurosci. 26, 3404-3411.

Cohen, A. S., and Abraham, W. C. (1996). Facilitation of long-term potentiation by prior activation of metabotropic glutamate receptors. J. Neurophysiol. 76, 953-962.

Collett, V. J., and Collingridge, G. L. (2004). Interactions between NMDA receptors and mGlu5 receptors expressed in HEK293 cells. Br. J. Pharmacol. 142, 991-1001.

Collingridge, G. L., Peineau, S., Howland, J. G., and Wang, Y. T. (2010). Long-term depression in the CNS. Nat. Rev. Neurosci. 11, 459-473.

Colombo, P. J., and Gallagher, M. (2002). Individual differences in spatial memory among aged rats are related to hippocampal PKCgamma immunoreactivity. Hippocampus 12, 285-289.

Colombo, P. J., Wetsel, W. C., and Gallagher, M. (1997). Spatial memory is related to hippocampal subcellular concentrations of calciumdependent protein kinase $\mathrm{C}$ isoforms in young and aged rats. Proc. Natl. Acad. Sci. U.S.A. 94, 14195-14199.

D'Agata, V., Warren, S. T., Zhao, W., Torre, E. R., Alkon, D. L., and Cavallaro, S. (2002). Gene expression profiles in a transgenic animal model of fragile X syndrome. Neurobiol. Dis. 10, 211-218.

Darnell, J. C., van Driesche, S. J., Zhang, C., Hung, K. Y., Mele, A., Fraser, C. E., et al. (2011). FMRP stalls ribosomal translocation on mRNAs linked to synaptic function and autism. Cell 146, 247-261.

Dolen, G., and Bear, M. F. (2008). Role for metabotropic glutamate receptor 5 (mGluR5) in the pathogenesis of fragile X syndrome. J. Physiol. (Lond.) 586, 1503-1508.
Dolen, G., Osterweil, E., Rao, B. S., Smith, G. B., Auerbach, B. D., Chattarji, S., et al. (2007). Correction of fragile X syndrome in mice. Neuron 56, 955-962.

Duncan, R. S., Hwang, S. Y., and Koulen, P. (2005). Effects of Vesl/Homer proteins on intracellular signaling. Exp. Biol. Med. 230, 527-535.

Fagni, L., Worley, P. F., and Ango, F. (2002). Homer as both a scaffold and transduction molecule. Sci. STKE 2002, re8.

Frankland, P. W., and Bontempi, B. (2005). The organization of recent and remote memories. Nat. Rev. Neurosci. 6, 119-130.

Gallagher, M., Burwell, R., and Burchinal, M. (1993). Severity of spatial learning impairment in aging: development of a learning index for performance in the Morris water maze. Behav. Neurosci. 107, 618-626.

Gallagher, M., Stocker, A. M., and Koh, M. T. (2011). Mindspan: lessons from rat models of neurocognitive aging. ILAR J. 52, 32-40.

Gallagher, S. M., Daly, C. A., Bear, M. F., and Huber, K. M. (2004). Extracellular signal-regulated protein kinase activation is required for metabotropic glutamate receptordependent long-term depression in hippocampal area CA1. J. Neurosci. 24, 4859-4864.

Gauthier, S., and Poirier, J. (2008). Current and future management of Alzheimer's disease. Alzheimer's Dement. 4, S48-S50.

Ge, Y., Dong, Z., Bagot, R. C., Howland, J. G., Phillips, A. G., Wong, T. P., et al. (2010). Hippocampal long-term depression is required for the consolidation of spatial memory. Proc. Natl. Acad. Sci. U.S.A. 107, 16697-16702.

Geinisman, Y., Ganeshina, O., Yoshida, R., Berry, R. W., Disterhoft, J. F., and Gallagher, M. (2004). Aging, spatial learning, and total synapse number in the rat CA1 stratum radiatum. Neurobiol. Aging 25, 407-416.

Gereau, R. W. T., and Heinemann, S. F. (1998). Role of protein kinase C phosphorylation in rapid desensitization of metabotropic glutamate receptor 5. Neuron 20, 143-151.

Giuffrida, R., Musumeci, S., D’Antoni, S., Bonaccorso, C. M., GiuffridaStella, A. M., Oostra, B. A., et al. (2005). A reduced number of metabotropic glutamate subtype 5 receptors are associated with constitutive homer proteins in a mouse model of fragile $\mathrm{X}$ syndrome. J. Neurosci. 25, 8908-8916.

Gocel, J., and Larson, J. (2012). Synaptic NMDA receptor-mediated currents in anterior piriform cortex are reduced in the adult fragile $\mathrm{X}$ mouse. Neuroscience 221, 170-181.

Godfraind, J. M., Reyniers, E., de Boulle, K., D’Hooge, R., de Deyn, P. P., Bakker, C. E., et al. (1996). Longterm potentiation in the hippocampus of fragile X knockout mice. Am. J. Med. Genet. 64, 246-251.

Gong, R., Park, C. S., Abbassi, N. R., and Tang, S. J. (2006). Roles of glutamate receptors and the mammalian target of rapamycin (mTOR) signaling pathway in activity-dependent dendritic protein synthesis in hippocampal neurons. J. Biol. Chem. 281, 18802-18815.

Gross, C., Nakamoto, M., Yao, X., Chan, C. B., Yim, S. Y., Ye, K., et al. (2010). Excess phosphoinositide 3kinase subunit synthesis and activity as a novel therapeutic target in fragile X syndrome. J. Neurosci. 30, 10624-10638.

Haberman, R. P., Colantuoni, C., Stocker, A. M., Schmidt, A. C., Pedersen, J. T., and Gallagher, M. (2011). Prominent hippocampal CA3 gene expression profile in neurocognitive aging. Neurobiol. Aging 32, 1678-1692.

Hou, L., Antion, M. D., Hu, D., Spencer, C. M., Paylor, R., and Klann, E (2006). Dynamic translational and proteasomal regulation of fragile $\mathrm{X}$ mental retardation protein controls mGluR-dependent long-term depression. Neuron 51, 441-454.

Hou, L., and Klann, E. (2004). Activation of the phosphoinositide 3-kinase-Akt-mammalian target of rapamycin signaling pathway is required for metabotropic glutamate receptor-dependent longterm depression. J. Neurosci. 24, 6352-6361.

Hu, J. H., Park, J. M., Park, S., Xiao, B., Dehoff, M. H., Kim, S., et al. (2010). Homeostatic scaling requires group I mGluR activation mediated by Homerla. Neuron 68 1128-1142.

Huber, K. M., Gallagher, S. M., Warren, S. T., and Bear, M. F. (2002). Altered synaptic plasticity in a mouse model of fragile $\mathrm{X}$ mental retardation. Proc. Natl. Acad. Sci. U.S.A. 99, 7746-7750.

Imayoshi, I., Sakamoto, M., Yamaguchi, M., Mori, K., and Kageyama, R. (2010). Essential roles of Notch signaling in maintenance of neural stem cells in developing and adult brains. J. Neurosci. 30, 3489-3498.

Izumi, Y., and Zorumski, C. F. (2012). NMDA receptors, mGluR5, and endocannabinoids are involved in a cascade leading to hippocampal 
long-term depression. Neuropsychopharmacology 37, 609-617.

Jacquemont, S., Birnbaum, S., Redler, S., Steinbach, P., and Biancalana, V. (2011). Clinical utility gene card for: fragile $\mathrm{X}$ mental retardation syndrome, fragile $\mathrm{X}$-associated tremor/ataxia syndrome and fragile $\mathrm{X}$-associated primary ovarian insufficiency. Eur. J. Hum. Genet. 19. doi: 10.1038/ejhg.2011.55

Jia, Z., Lu, Y., Henderson, J., Taverna, F., Romano, C., Abramow-Newerly, W., et al. (1998). Selective abolition of the NMDA component of longterm potentiation in mice lacking mGluR5. Learn. Mem. 5, 331-343.

Jia, Z., Lu, Y. M., Agopyan, N., and Roder, J. (2001). Gene targeting reveals a role for the glutamate receptors mGluR5 and GluR2 in learning and memory. Physiol. Behav. 73, 793-802.

Jones, M. W., Errington, M. L., French, P. J., Fine, A., Bliss, T. V., Garel, S., et al. (2001). A requirement for the immediate early gene Zif268 in the expression of late LTP and longterm memories. Nat. Neurosci. 4, 289-296.

Kammermeier, P. J., and Worley, P. F. (2007). Homer la uncouples metabotropic glutamate receptor 5 from postsynaptic effectors. Proc. Natl. Acad. Sci. U.S.A. 104, 6055-6060.

Kawabata, S., Tsutsumi, R., Kohara, A., Yamaguchi, T., Nakanishi, S., and Okada, M. (1996). Control of calcium oscillations by phosphorylation of metabotropic glutamate receptors. Nature 383, 89-92.

Kellner, A., Matschke, J., Bernreuther, C., Moch, H., Ferrer, I., and Glatzel, M. (2009). Autoantibodies against betaamyloid are common in Alzheimer's disease and help control plaque burden. Ann. Neurol. 65, 24-31.

Kemp, A., and Manahan-Vaughan, D. (2007). Hippocampal longterm depression: master or minion in declarative memory processes? Trends Neurosci. 30, 111-118.

Kim, C. H., Lee, J., Lee, J. Y., and Roche, K. W. (2008). Metabotropic glutamate receptors: phosphorylation and receptor signaling. J. Neurosci. Res. 86, 1-10.

Kim, R., Moki, R., and Kida, S. (2011). Molecular mechanisms for the destabilization and restabilization of reactivated spatial memory in the Morris water maze. Mol. Brain 4,

Kim, S. E., Ko, I. G., Kim, B. K., Shin, M. S., Cho, S., Kim, C. J., et al. (2010a). Treadmill exercise prevents aging-induced failure of memory through an increase in neurogenesis and suppression of apoptosis in rat hippocampus. Exp. Gerontol. 45, 357-365.

Kim, S. H., Fraser, P. E., Westaway, D., St George-Hyslop, P. H., Ehrlich, M. E., and Gandy, S. (2010b). Group II metabotropic glutamate receptor stimulation triggers production and release of Alzheimer's amyloid(beta) 42 from isolated intact nerve terminals. J. Neurosci. 30, 3870-3875.

Klugmann, M., Symes, C. W., Leichtlein, C. B., Klaussner, B. K., Dunning, J., Fong, D., et al. (2005). AAVmediated hippocampal expression of short and long Homer 1 proteins differentially affect cognition and seizure activity in adult rats. Mol. Cell. Neurosci. 28, 347-360.

Kollen, M., Stephan, A., Faivre-Bauman, A., Loudes, C., Sinet, P. M., Alliot, J., et al. (2010). Preserved memory capacities in aged Lou/C/Jall rats. Neurobiol. Aging 31, 129-142.

Kremen, W. S., Lachman, M. E., Pruessner, J. C., Sliwinski, M., and Wilson, R. S. (2012). Mechanisms of agerelated cognitive change and targets for intervention: social interactions and stress. J. Gerontol. A Biol. Sci. Med. Sci. 67, 760-765.

Krueger, D. D., and Bear, M. F. (2011). Toward fulfilling the promise of molecular medicine in fragile $\mathrm{X}$ syndrome. Annu. Rev. Med. 62, 411-429.

Kumar, A. (2011). Long-term potentiation at CA3-CA1 hippocampal synapses with special emphasis on aging, disease, and stress. Front. Aging Neurosci. 3:7. doi:10.3389/fnagi.2011.00007

Larson, J., Jessen, R. E., Kim, D., Fine, A. K., and Du Hoffmann, J. (2005). Age-dependent and selective impairment of long-term potentiation in the anterior piriform cortex of mice lacking the fragile $\mathrm{X}$ mental retardation protein. J. Neurosci. 25, 9460-9469.

Lee, H. K., Min, S. S., Gallagher, M., and Kirkwood, A. (2005). NMDA receptor-independent longterm depression correlates with successful aging in rats. Nat. Neurosci. 8, 1657-1659.

Lee, J. H., Lee, J., Choi, K. Y., Hepp, R., Lee, J. Y., Lim, M. K., et al. (2008). Calmodulin dynamically regulates the trafficking of the metabotropic glutamate receptor mGluR5. Proc. Natl. Acad. Sci. U.S.A. 105, 12575-12580.

Lee, Y. S., and Silva, A. J. (2009). The molecular and cellular biology of enhanced cognition. Nat. Rev. Neurosci. 10, 126-140.
Liu, J. X., Tang, Y. C., Liu, Y., and Tang, F. R. (2008). mGluR5-PLCbeta4PKCbeta2/PKCgamma pathways in hippocampal CAl pyramidal neurons in pilocarpine model of status epilepticus in mGluR5+/+ mice. Epilepsy Res. 82, 111-123.

Lu, Y. M., Jia, Z., Janus, C., Henderson, J. T., Gerlai, R., Wojtowicz, J. M., et al. (1997). Mice lacking metabotropic glutamate receptor 5 show impaired learning and reduced CA1 long-term potentiation (LTP) but normal CA3 LTP. J. Neurosci. 17, 5196-5205.

Lucin, K. M., and Wyss-Coray, T. (2009). Immune activation in brain aging and neurodegeneration: too much or too little? Neuron 64, 110-122.

Luscher, C., and Huber, K. M. (2010). Group 1 mGluR-dependent synaptic long-term depression: mechanisms and implications for circuitry and disease. Neuron 65, 445-459.

Malleret, G., Alarcon, J. M., Martel, G. Takizawa, S., Vronskaya, S., Yin, D. et al. (2010). Bidirectional regulation of hippocampal long-term synaptic plasticity and its influence on opposing forms of memory. J. Neurosci. 30 , 3813-3825.

Malleret, G., Haditsch, U., Genoux, D. Jones, M. W., Bliss, T. V., Vanhoose, A. M., et al. (2001). Inducible and reversible enhancement of learning, memory, and long-term potentiation by genetic inhibition of calcineurin. Cell 104, 675-686.

Manahan-Vaughan, D., and Braunewell, K. H. (2005). The metabotropic glutamate receptor, mGluR5, is a key determinant of good and bad spatial learning performance and hippocampal synaptic plasticity. Cereb. Cortex 15, 1703-1713.

Mao, L. M., Liu, X. Y., Zhang, G. C., Chu, X. P., Fibuch, E. E., Wang, L. S., et al. (2008). Phosphorylation of group I metabotropic glutamate receptors (mGluR1/5) in vitro and in vivo. Neuropharmacology 55, 403-408.

Masu, M., Tanabe, Y., Tsuchida, K. Shigemoto, R., and Nakanishi, S. (1991). Sequence and expression of a metabotropic glutamate receptor. Nature 349, 760-765.

McBride, S. M., Choi, C. H., Schoenfeld, B. P., Bell, A. J., Liebelt, D. A., Ferreiro, D., et al. (2010). Pharmacological and genetic reversal of agedependent cognitive deficits attributable to decreased presenilin function. J. Neurosci. 30, 9510-9522.

McBride, S. M., Choi, C. H., Wang, Y., Liebelt, D., Braunstein, E., Ferreiro, D., et al. (2005). Pharmacological rescue of synaptic plasticity, courtship behavior, and mushroom body defects in a Drosophila model of fragile X syndrome. Neuron 45 , 753-764.

Menard, C., and Quirion, R. (2012). Successful cognitive aging in rats: a role for mGluR5 glutamate receptors, homer 1 proteins and downstream signaling pathways. PLoS ONE 7, e28666. doi:10.1371/journal.pone.0028666

Monti, B., Berteotti, C., and Contestabile, A. (2005). Dysregulation of memory-related proteins in the hippocampus of aged rats and their relation with cognitive impairment. Hippocampus 15, 1041-1049.

Morris, R. (1984). Developments of a water-maze procedure for studying spatial learning in the rat. J. Neurosci. Methods 11, 47-60.

Mulder, J., Zilberter, M., Pasquare, S. J., Alpar, A., Schulte, G., Ferreira, S. G., et al. (2011). Molecular reorganization of endocannabinoid signalling in Alzheimer's disease. Brain 134, 1041-1060.

Mulkey, R. M., and Malenka, R. C. (1992). Mechanisms underlying induction of homosynaptic longterm depression in area CA1 of the hippocampus. Neuron 9, 967-975.

Neasta, J., Ben Hamida, S., Yowell, Q., Carnicella, S., and Ron, D. (2010). Role for mammalian target of rapamycin complex 1 signaling in neuroadaptations underlying alcohol-related disorders. Proc. Natl. Acad. Sci. U.S.A. 107, 20093-20098.

Neyman, S., and Manahan-Vaughan, D. (2008). Metabotropic glutamate receptor 1 (mGluR1) and 5 (mGluR5) regulate late phases of LTP and LTD in the hippocampal CA1 region in vitro. Eur. J. Neurosci. 27, 1345-1352.

Nicholson, D. A., Yoshida, R., Berry, R. W., Gallagher, M., and Geinisman, Y. (2004). Reduction in size of perforated postsynaptic densities in hippocampal axospinous synapses and age-related spatial learning impairments. J. Neurosci. 24, 7648-7653.

Nicoletti, F., Bockaert, J., Collingridge, G. L., Conn, P. J., Ferraguti, F., Schoepp, D. D., et al. (2011). Metabotropic glutamate receptors: from the workbench to the bedside. Neuropharmacology 60, 1017-1041.

Nicolle, M. M., Gallagher, M., and McKinney, M. (1999). No loss of synaptic proteins in the hippocampus of aged, behaviorally impaired rats. Neurobiol. Aging 20, 343-348.

Nithianantharajah, J., and Murphy, M. (2009). Experience on the Barnes spatial maze influences PKCgamma levels in the hippocampus. Int. J. Neurosci. 119, 1014-1030. 
Nosyreva, E. D., and Huber, K. M. (2006). Metabotropic receptordependent long-term depression persists in the absence of protein synthesis in the mouse model of fragile X syndrome. J. Neurophysiol. 95, 3291-3295.

Nyffeler, M., Yee, B. K., Feldon, J., and Knuesel, I. (2010). Abnormal differentiation of newborn granule cells in age-related working memory impairments. Neurobiol. Aging 31, 1956-1974.

Nyffeler, M., Zhang, W. N., Feldon, J., and Knuesel, I. (2007). Differential expression of PSD proteins in age-related spatial learning impairments. Neurobiol. Aging 28, 143-155.

O’Brien, R. J., Kamboj, S., Ehlers, M. D., Rosen, K. R., Fischbach, G. D., and Huganir, R. L. (1998). Activitydependent modulation of synaptic AMPA receptor accumulation. $\mathrm{Neu}$ ron 21, 1067-1078.

Orlando, L. R., Ayala, R., Kett, L. R., Curley, A. A., Duffner, J., Bragg, D. C., et al. (2009). Phosphorylation of the homer-binding domain of group I metabotropic glutamate receptors by cyclin-dependent kinase 5 . J. Neurochem. 110, 557-569.

Osterweil, E. K., Krueger, D. D., Reinhold, K., and Bear, M. F. (2010). Hypersensitivity to mGluR5 and ERK1/2 leads to excessive protein synthesis in the hippocampus of a mouse model of fragile $\mathrm{X}$ syndrome. J. Neurosci. 30, 15616-15627.

Page, G., Khidir, F. A., Pain, S., Barrier, L., Fauconneau, B., Guillard, O., et al. (2006). Group I metabotropic glutamate receptors activate the p70S6 kinase via both mammalian target of rapamycin (mTOR) and extracellular signal-regulated kinase (ERK 1/2) signaling pathways in rat striatal and hippocampal synaptoneurosomes. Neurochem. Int. 49, 413-421.

Palmer, M. J., Irving, A. J., Seabrook, G. R., Jane, D. E., and Collingridge, G. L. (1997). The group I mGlu receptor agonist DHPG induces a novel form of LTD in the CA1 region of the hippocampus. Neuropharmacology 36, 1517-1532.

Park, S., Park, J. M., Kim, S., Kim, J. A., Shepherd, J. D., Smith-Hicks, C. L., et al. (2008). Elongation factor 2 and fragile $\mathrm{X}$ mental retardation protein control the dynamic translation of Arc/Arg3.1 essential for mGluR-LTD. Neuron 59, 70-83.

Parsons, R. G., Gafford, G. M., and Helmstetter, F. J. (2006). Translational control via the mammalian target of rapamycin pathway is critical for the formation and stability of long-term fear memory in amygdala neurons. J. Neurosci. 26, 12977-12983.

Pasic, M. D., Diamandis, E. P., McLaurin, J., Holtzman, D. M., SchmittULMS, G., and Quirion, R. (2011). Alzheimer disease: advances in pathogenesis, diagnosis, and therapy. Clin. Chem. 57, 664-669.

Penner, M. R., Roth, T. L., Barnes, C. A., and Sweatt, J. D. (2010). An epigenetic hypothesis of aging-related cognitive dysfunction. Front. Aging Neurosci. 2:9. doi:10.3389/fnagi.2010.00009

Pieretti, M., Zhang, F. P., Fu, Y. H., Warren, S. T., Oostra, B. A., Caskey, C. T., et al. (1991). Absence of expression of the FMR-1 gene in fragile $\mathrm{X}$ syndrome. Cell 66, 817-822.

Rapp, P. R., and Gallagher, M. (1996). Preserved neuron number in the hippocampus of aged rats with spatial learning deficits. Proc. Natl. Acad. Sci. U.S.A. 93, 9926-9930.

Reichel, C. M., Schwendt, M., McGinty, J. F., Olive, M. F., and See, R. E. (2011). Loss of object recognition memory produced by extended access to methamphetamine self-administration is reversed by positive allosteric modulation of metabotropic glutamate receptor 5. Neuropsychopharmacology 36, 782-792.

Renner, M., Lacor, P. N., Velasco, P. T., $\mathrm{Xu}$, J., Contractor, A., Klein, W. L., et al. (2010). Deleterious effects of amyloid beta oligomers acting as an extracellular scaffold for mGluR5. Neuron 66, 739-754.

Richards, G., Messer, J., Faull, R. L., Stadler, H., Wichmann, J., Huguenin, P., et al. (2010). Altered distribution of mGlu2 receptors in beta-amyloidaffected brain regions of Alzheimer cases and aged PS2APP mice. Brain Res. 1363, 180-190.

Roche, K. W., Tu, J. C., Petralia, R. S., Xiao, B., Wenthold, R. J., and Worley, P. F. (1999). Homer $1 b$ regulates the trafficking of group I metabotropic glutamate receptors. J. Biol. Chem. 274, 25953-25957.

Romano, C., van Den Pol, A. N., and O’Malley, K. L. (1996). Enhanced early developmental expression of the metabotropic glutamate receptor mGluR5 in rat brain: protein, mRNA splice variants, and regional distribution. J. Comp. Neurol. 367, 403-412.

Ronesi, J. A., Collins, K. A., Hays, S. A., Tsai, N. P., Guo, W., Birnbaum, S. G., et al. (2012). Disrupted Homer scaffolds mediate abnormal mGluR5 function in a mouse model of fragile X syndrome. Nat. Neurosci. $15,431-440$.

Ronesi, J. A., and Huber, K. M. (2008). Homer interactions are necessary for metabotropic glutamate receptorinduced long-term depression and translational activation. J. Neurosci. 28, 543-547.

Roselli, F., Hutzler, P., Wegerich, Y., Livrea, P., and Almeida, O. F. (2009). Disassembly of shank and homer synaptic clusters is driven by soluble beta-amyloid(1-40) through divergent NMDAR-dependent signalling pathways. PLoS ONE 4, e6011. doi:10.1371/journal.pone.0006011

Rowe, W. B., Blalock, E. M., Chen, K. C., Kadish, I., Wang, D., Barrett, J. E., et al. (2007). Hippocampal expression analyses reveal selective association of immediate-early, neuroenergetic, and myelinogenic pathways with cognitive impairment in aged rats. J. Neurosci. 27 3098-3110.

Rowe, W. B., Spreekmeester, E., Meaney, M. J., Quirion, R., and Rochford, J. (1998). Reactivity to novelty in cognitively-impaired and cognitively-unimpaired aged rats and young rats. Neuroscience 83 669-680.

Serge, A., Fourgeaud, L., Hemar, A., and Choquet, D. (2002). Receptor activation and homer differentially control the lateral mobility of metabotropic glutamate receptor 5 in the neuronal membrane. J. Neurosci. 22, 3910-3920.

Shepherd, J. D., and Bear, M. F. (2011). New views of Arc, a master regulator of synaptic plasticity. Nat. Neurosci. 14, 279-284.

Shiraishi-Yamaguchi, Y., and Furuichi, T. (2007). The Homer family proteins. Genome Biol. 8, 206.

Simonyi, A., Schachtman, T. R., and Christoffersen, G. R. (2010). Metabotropic glutamate receptor subtype 5 antagonism in learning and memory. Eur. J. Pharmacol. 639, 17-25.

Sokol, D. K., Maloney, B., Long, J. M., Ray, B., and Lahiri, D. K. (2011). Autism, Alzheimer disease, and fragile X: APP, FMRP, and mGluR5 are molecular links. Neurology 76 1344-1352.

Sun, M. K., and Alkon, D. L. (2010). Pharmacology of protein kinase $C$ activators: cognition-enhancing and antidementic therapeutics. Pharmacol. Ther. 127, 66-77.

Tronson, N. C., Guzman, Y. F., Guedea, A. L., Huh, K. H., Gao, C., Schwarz, M. K., et al. (2010). Metabotropic glutamate receptor 5/Homer interactions underlie stress effects on fear. Biol. Psychiatry 68, 1007-1015.

Tsai, V. W., Scott, H. L., Lewis, R. J., and Dodd, P. R. (2005). The role of group I metabotropic glutamate receptors in neuronal excitotoxicity in Alzheimer's disease. Neurotox. Res. 7, 125-141.

Tu, J. C., Xiao, B., Naisbitt, S., Yuan, J. P., Petralia, R. S., Brakeman, P., et al. (1999). Coupling of mGluR/Homer and PSD-95 complexes by the Shank family of postsynaptic density proteins. Neuron 23, 583-592.

Tu, J. C., Xiao, B., Yuan, J. P., Lanahan, A. A., Leoffert, K., Li, M., et al. (1998). Homer binds a novel proline-rich motif and links group 1 metabotropic glutamate receptors with IP3 receptors. Neuron 21, 717-726.

Turrigiano, G. G., and Nelson, S. B. (2000). Hebb and homeostasis in neuronal plasticity. Curr. Opin. Neurobiol. 10, 358-364.

van Keuren-Jensen, K., and Cline, H. T. (2006). Visual experience regulates metabotropic glutamate receptor-mediated plasticity of AMPA receptor synaptic transmission by homerla induction. $J$. Neurosci. 26, 7575-7580.

Villeda, S. A., Luo, J., Mosher, K. I., Zou, B., Britschgi, M., Bieri, G., et al. (2011). The ageing systemic milieu negatively regulates neurogenesis and cognitive function. Nature 477, 90-94.

von Bernhardi, R., Tichauer, J. E., and Eugenin, J. (2010). Aging-dependent changes of microglial cells and their relevance for neurodegenerative disorders. J. Neurochem. 112, 1099-1114.

Wang, H., Nong, Y., Bazan, F., Greengard, P., and Flajolet, M. (2010). Norbin: a promising central nervous system regulator. Commun. Integr. Biol. 3, 487-490.

Wang, H., Westin, L., Nong, Y., Birnbaum, S., Bendor, J., Brismar, H. et al. (2009). Norbin is an endogenous regulator of metabotropic glutamate receptor 5 signaling. Science 326, 1554-1557.

Weiler, I. J., Irwin, S. A., Klintsova, A. Y., Spencer, C. M., Brazelton, A. D., Miyashiro, K., et al. (1997). Fragile X mental retardation protein is translated near synapses in response to neurotransmitter activation. Proc. Natl. Acad. Sci. U.S.A. 94, 5395-5400.

Westmark, C. J., and Malter, J. S. (2007). FMRP mediates mGluR5dependent translation of amyloid precursor protein. PLoS Biol. 5, e52. doi:10.1371/journal.pbio.0050052 
Williams, B. J., Bimonte-Nelson, H. A., and Granholm-Bentley, A. C. (2006). ERK-mediated NGF signaling in the rat septo-hippocampal pathway diminishes with age. Psychopharmacology (Berl.) 188, 605-618.

Wilson, I. A., Gallagher, M., Eichenbaum, H., and Tanila, H. (2006). Neurocognitive aging: prior memories hinder new hippocampal encoding. Trends Neurosci. 29, 662-670.

Xiao, B., Tu, J. C., Petralia, R. S., Yuan, J. P., Doan, A., Breder, C. D., et al. (1998). Homer regulates the association of group 1 metabotropic glutamate receptors with multivalent complexes of homer-related, synaptic proteins. Neuron 21, 707-716.

Xiao, B., Tu, J. C., and Worley, P. F. (2000). Homer: a link between neural activity and glutamate receptor function. Curr. Opin. Neurobiol. 10, 370-374.

$\mathrm{Xu}$, J., Zhu, Y., Contractor, A., and Heinemann, S. F. (2009). mGluR5 has a critical role in inhibitory learning. J. Neurosci. 29, 3676-3684.

Xu, W., Wong, T. P., Chery, N., Gaertner, T., Wang, Y. T., and Baudry, M. (2007). Calpain-mediated mGluRlalpha truncation: a key step in excitotoxicity. Neuron 53, 399-412.

Yan, Q. J., Rammal, M., Tranfaglia, M., and Bauchwitz, R. P. (2005). Suppression of two major Fragile $\mathrm{X}$ Syndrome mouse model phenotypes by the mGluR5 antagonist MPEP. Neuropharmacology 49, 1053-1066.

Yang, L., Mao, L., Tang, Q., Samdani, S., Liu, Z., and Wang, J. Q. (2004). A novel Ca2 ${ }^{+}$-independent signaling pathway to extracellular signal-regulated protein kinase by coactivation of NMDA receptors and metabotropic glutamate receptor 5 in neurons. J. Neurosci. 24, 10846-10857.

Zadran, S., Bi, X., and Baudry, M. (2010). Regulation of calpain-2 in neurons: implications for synaptic plasticity. Mol. Neurobiol. 42, 143-150.

Zhang, G. R., Liu, M., Cao, H., Kong, L., Wang, X., O'Brien, J. A., et al. (2009). Improved spatial learning in aged rats by genetic activation of protein kinase $\mathrm{C}$ in small groups of hippocampal neurons. Hippocampus 19, 413-423.

Zhao, X., Rosenke, R., Kronemann, D., Brim, B., Das, S. R., Dunah, A. W., et al. (2009). The effects of aging on N-methyl-D-aspartate receptor subunits in the synaptic membrane and relationships to long-term spatial memory. Neuroscience 162 933-945.

Zukin, R. S., Richter, J. D., and Bagni, C. (2009). Signals, synapses, and synthesis: how new proteins control plasticity. Front. Neural Circuits 3:14 doi:10.3389/neuro.04.014

Conflict of Interest Statement: The authors declare that the research was conducted in the absence of any commercial or financial relationships that could be construed as a potential conflict of interest.

Received: 12 July 2012; paper pending published: 01 August 2012; accepted: 23 September 2012; published online: 12 October 2012.

Citation: Ménard $C$ and Quirion $R$ (2012) Group 1 metabotropic glutamate receptor function and its regulation of learning and memory in the aging brain. Front. Pharmacol. 3:182. doi: 10.3389/fphar.2012.00182

This article was submitted to Frontiers in Neuropharmacology, a specialty of Frontiers in Pharmacology.

Copyright (C) 2012 Ménard and Quirion. This is an open-access article distributed under the terms of the Creative Commons Attribution License, which permits use, distribution and reproduction in other forums, provided the original authors and source are credited and subject to any copyright notices concerning any third-party graphics etc. 